\title{
PEMBUATAN SEDIAAN MINYAK GOSOK DARI BAHAN KELAPA (Cocos nucifera L.), SERAI (Cymbopogon citratus DC.) dan DAUN DEWA (Gynura segetum L.) dengan METODE PENGENDAPAN TRADISIONAL
}

\author{
Rickson Tanka ${ }^{1}$,Susi Andriani ${ }^{2}$,Yusi Helmiawati ${ }^{3}$ \\ 1,2,3 Sekolah Tinggi Ilmu Kesehatan Holistik Purwakarta
}

\begin{abstract}
ABSTRAK
Latar belakang : Tumbuhan merupakan keragaman hayati yang ada di sekitar kita, baik itu yang tumbuh secara liar maupun yang sengaja dibudidayakan. Sejak zaman dahulu, tumbuhan sudah digunakan sebagai tanaman obat, walaupun penggunaannya disebarkan secara turun-temurun maupun dari mulut ke mulut.

Tujuan : Penelitian ini bertujuan untuk menyediakan sediaan jadi herbal yang dapat digunakan oleh masyarakat untuk pengobatan masuk angin.

Metode : Penelitian ini merupakan penelitian deskriptif yang dikembangkan oleh masyarakat secara turun-temurun, dilakukan wawancara kepada masyarakat mengenai khasiat minyak kelapa murni ( virgin coconut oil ) dengan campuran serai (Cymbopogon citratus DC.) dan daun dewa (Gynura segetum L.) untuk kerik masuk angin. Dalam penelitian ini membuat sediaan minyak gosok dari kelapa (Cocos nucifera L.) yang menjadi minyak kelapa murni dengan tambahan serai dan daun dewa sebagai kerik masuk angin melalui proses pengendapan selama empat hari dengan menggunakan pelarut air. Minyak gosok dibuat dengan bahan kelapa dua kilogram yang diparut ditambahkan air sebanyak satu liter sebanyak dua kali perasan, didapat santan sebanyak $1800 \mathrm{~mL}$ lalu saring santan, hasil saringan endapkan selama tiga hari menghasilkan minyak kelapa murni sebanyak $200 \mathrm{ml}$, setalah menjadi minyak kelapa murni (virgin coconut oil) tambahkan serai (Cymbopogon citratus DC.) sebanyak 20 gram dan daun dewa (Gynura segetum L.) 20 gram yang sudah dipotong-potong diendapkan selama satu hari kemudian disaring dan menghasilkan minyak gosok lima botol dengan masing-masing berat $20 \mathrm{~mL}$.

Hasil : Pengujian organoleptis sediaan dilakukan selama tiga minggu dengan hasil yang menunjukan bahwa tidak ada perubahan negatif yang terjadi dari bentuk, warna, bau, rasa maupun pertumbuhan jamur.

Simpulan : Penelitian ini berhasil membuat sediaan dalam bentuk minyak gosok yang dapat bertahan selama tiga minggu.
\end{abstract}

Kata kunci: minyak, kelapa, masuk angin, kerik

Korespondensi :

Susi Andriani

Program Studi D3 Farmasi, STIKes Holistic Purwakarta

J1. Veteran No.272 Ciseureuh Purwakarta

Email : susi_andriani08@yahoo.co.id

Phone : 0857-2156-0088 


\title{
MAKING LINIMENT OIL from COCONUT (Cocos nucifera L.),LEMONGRASS (Cymbopogon citratus DC.)and GOD LEAF (Gynura segetum L.)with TRADITIONAL SETTLING METHOD
}

\begin{abstract}
Backgroud : Plant is a biodiversity that all around us, whether it was growing wild and cultivated intentionally. Herbs have been used as a medicinal plant, although its use spread by generations.

The aim: This research aim to provide the herbs that can be used by the community for the treatment of colds.

Method : This research is a descriptive study developed by the community for generations, conducted interviews to the public regarding the efficacy of pure coconut oil (virgin coconut oil) with a mixture of lemongrass (Cymbopogon citratus DC.) and god leaf (Gynura segetum L.) for currycomb. In this reasearch made preparations ointment of coconut (Cocos nucifera L.) which become extract virgin coconut oil with lemongrass and god leaf as currycomb through the deposition process for four days using water-soluble. Ointments made with the coconut two kilograms of shredded added to water as much as one liter of two times juice, in the can of coconut milk as much as $1800 \mathrm{ml}$ and filtered coconut milk, settling for three days to produce virgin coconut oil $200 \mathrm{cc}$, pure coconut oil (VCO) add lemongrass (Cymbopogon citratus DC.) of 20 grams and leaves god (Gynura segetum L.) 20 grams chopped settling for one day then filtered and generate ointment five bottles with each weight $20 \mathrm{cc}$.

Result : Results showing test organoleptic dosage for three weeks are not changes the shape, color, taste and smell of mold growth.

Conclusion : Research is successful prepare an ointment hold for three weeks.
\end{abstract}

Keywords: oil, coconut, colds, currycomb 


\section{PENDAHULUAN}

Kelapa merupakan salah satu tanaman yang banyak terdapat di negara negara tropis salah satunya adalah Indonesia. Hampir di semua propinsi di Indonesia dijumpai tanaman kelapa yang merupakan tanaman perkebunan rakyat. Hal ini merupakan peluang untuk pengembangan kelapa menjadi aneka produk yang bermanfaat.

Saat ini di Desa Bungursari Kabupaten Purwakarta, banyak memanfaatkan minyak kelapa sebagai bahan kesehatan yang dioleskan pada kulit yang fungsinya sebagai minyak gosok dan kerik, sifatnya tidak mudah menguap dan melekat, sesuai untuk minyak gosok, kerik dan pijat telapak kaki karena tidak perih di permukaan kulit.

$$
\text { Tumbuhan merupakan }
$$

keragaman hayati yang ada di sekitar kita, baik itu yang tumbuh secara liar maupun yang sengaja dibudidayakan.

Sejak zaman dahulu, tumbuhan sudah digunakan sebagai tanaman obat, walaupun penggunaannya disebarkan secara turun-temurun maupun dari mulut ke mulut.
Pohon kelapa sangat bermanfaat bagi kehidupan manusia karena hampir semua bagian kelapa dapat dimanfaatkan. Buah kelapa yang terdiri atas sabut, tempurung, daging buah dan air kelapa tidak ada yang terbuang dan dapat dibuat untuk menghasilkan produk industri, antara lain sabut kelapa dapat dibuat keset, sapu dan matras. Tempurung dapat dimanfaatkan untuk membuat karbon aktif dan kerajinan tangan. Dari batang kelapa dapat dihasilkan bahan-bahan bangunan baik untuk kerangka maupun untuk dinding serta atap. Daun kelapa dapat diambil lidinya yang dapat dipakai sebagai sapu, serta barang-barang anyaman. Daging buah kelapa dapat dipakai sebagai bahan baku untuk menghasilkan kopra, minyak kelapa, coconut cream, santan dan parutan kering. Sedangkan air kelapa dapat dipakai untuk membuat cuka dan nata de coco.

Santan adalah cairan yang dapat diperoleh dengan melakukan pemerasan terhadap daging buah kelapa yang telah diparut. Santan merupakan bahan makanan yang dipergunakan untuk mengolah 
berbagai masakan yang mengandung daging, ikan, ayam dan untuk pembuatan berbagai kue-kue, es krim, gula-gula. Selain itu kelapa juga menghasilkan produk olahan yang popular belakangan ini yaitu virgin coconut oil yang sering disingkat menjadi VCO yang bermanfaat bagi kehidupan manusia.

Minyak kelapa murni (virgin coconut oil) adalah produk herbal yang banyak mendapat perhatian masyarakat. Hal itu dikarenakan pernyataan akan suatu fakta (klaim) dan berdasarkan pengalaman terutama yang diperoleh dari penemuan, percobaan, pengamatan yang telah dilakukan (bukti empiris) sebagai salah satu obat untuk beberapa penyakit (panasea), yang diharapkan mendapatkan khasiat yang lebih besar setelah dikombinasikan dengan beberapa tumbuhan herbal lainnya.

Minyak kelapa murni (virgin coconut oil) secara alamiah telah terbukti aman digunakan oleh manusia dan oleh Food and Drugs Administration (FDA), Amerika Serikat, telah digolongkan sebagai bahan GRAS (Generally Regarded As
Safe). Minyak kelapa murni (virgin coconut oil) bermanfaat sebagai penyembuhan ruam kulit serta penyembuhan mati jaringan kulit (decubitus) Sere bermanfaat sebagai analgetik serta anti bakterisedangkan daun dewa bermanfaat sebagai penyembuh luka. ${ }^{1}$

Berdasarkan hal itu tersebut di atas, maka penulis tertarik untuk membuat sediaan minyak gosok berbahan Cocos nucifera $L$. (kelapa) yang digabungkan dengan Cymbopogon citratus DC. (sere), dan Gynura segetum $L$. (daun dewa) dalam bentuk kombinasi minyak gosok ketiganya dengan cara pengendapan tradisionalyaitu serei dan daun dewa diendapkan ke dalam minyak kelapa.

\section{METODE PENELITIAN}

$$
\text { Pada penelitian ini }
$$
menggunakan metodedeskriptif yaitu penelitian yang dilakukan untuk menggambarkan karateristik suatu kelompok subyek tertentu. Dengan melakukan pengumpulan data observasi dan wawancara kepada masyarakat. Penelitian dengan 
metode wawancara dimaksudkan untuk mengetahui cara pembuatan sediaan tradisional dari herbal dengan bahan baku Cocos nucifera L. (kelapa) yang digabungkan dengan Cymbopogon citratus DC. (sere) dan Gynura segetum L. (daun dewa) yang dibuat menjadi sediaan minyak gosok dengan metode pengendapan secara tradisional ${ }^{2}$ dan sudah dilakukan secara turun temurun dan untuk mengetahui bagaimana pembuatan sediaan minyak gosok dari VCO dengan tambahan serai dan daun dewa yang pernah dibuat oleh masyarakat. Ada beberapa tahapan seperti pengumpulan bahan, dan pembuatan sediaan menjadi minyak gosok.

Dalam penelitian ini yang diwawancarai adalah masyarakat sebanyak 15 orang dengan usia 35 sampai 62 tahun dengan beragam pekerjaaan. Pembuatan minyak kelapa muri (VCO) dengan bahan dasar kelapa $2 \mathrm{~kg}$ dengan informasi hasil wawancara diparut, lalu disaring dan endapkan. Setelah menjadi minyak kelapa murni, tambahkan batang serai dan daun dewa kedalam minyak kelapa murni, endapkan lagi dan menjadi minyak gosok.

Lokasi wawancara dipilih Desa Bungursari Kabupaten Purwakarta, alasan memilih Desa Bungursari Kabupaten Purwakarta karena di sekitar wilayah tersebut banyak sekali tanaman kelapa dan penduduk sekitar sering menjual buah kelapa di depan rumah mereka.

\section{HASIL PENELITIAN}

\section{Penyiapan bahan}

Kelapa yang digunakan untuk pembuatan minyak kelapa dipilih kelapa yang sudah tua artinya dagingnya sudah siap untuk digunakan sebagai bahan baku untuk pembuatan minyak kelapa murni, kelapa diperoleh dari Desa Bungursari Kabupaten Purwakarta, sere yang diambil dipastikan masih berwarna hijau tidak berwarna coklat atau kekuning-kuningan karena sere yang masih hijau menunjukan sere masih segar, sedangkan untuk pembuatan minyak gosok diperlukan sere yang aromanya masih menyengat, sere diperoleh dari Desa Bungursari Kabupaten Purwakarta sedangkan untuk daun dewa 
pemilihannya hampir sama dengan sere dipilih daun yang masih segar.

\section{Wawancara}

Pada persiapan sampai dengan pembuatan sediaan ini hingga menjadi sediaan yang sudah jadi, dilakukan dengan waktu selama tiga bulan, dan melakukan wawancara sebanyak 15 orang dengan usia antara 20 sampai dengan 60 tahun, untuk mengetahui bagaimana masyarakat mengenal minyak gosok dari kelapa. Dari hasil wawancara, mereka pernah menggunakan minyak gosok dari bahan minyak kelapa murni (virgin coconut oil) untuk kerik terutama saat merasa keluhan sakit yang umumnya disebut masuk angin, Gigitan serangga, Bengkak dan diminum stamina karena mudah diperoleh dan mudah digunakan serta dapat disimpan dalam waktu yang lama.

Tabel 1. Hasil wawancara khasiat minyak gosok

\begin{tabular}{lll}
\hline Keluhan sakit & Hasil pengamatan & Keterangan \\
\hline $\begin{array}{l}\text { Masuk angin } \\
\text { Gigitan serangga dan } \\
\text { pengusir nyamuk }\end{array}$ & 14 orang & Pernah menggunakan \\
Bengkak kulit & 2 orang & Pernah menggunakan \\
Untuk stamina & 1 orang & Pernah menggunakan \\
\hline
\end{tabular}

\section{PEMBAHASAN}

Dari hasil penelitian, pembuatan minyak gosok dari bahan kelapa, serai, dan daun dewa membutuhkan waktu selama empat hari pengendapan minyak kelapa murni tiga hari ditambahkan pengendapan sere dan daun dewa ke dalam minyak kelapa murni yang sudah jadi selama satu hari. Pada proses pengendapan minyak kelapa murni (virgin coconut oil) yang diproses selama tiga hari dan secara tradisional dengan alat-alat sederhana tanpa zat tambahan terlihat lebih bening seperti warna air mineral dibandingkan dengan menggunakan bantuan fermentasi enzym atau dengan waktu yang kurang dari tiga hari. 
Minyak kelapa murni (virgin coconut oil) menggunakan pelarut air matang yang ditambahkan kedalam daging kelapa yang sudah diparut lalu diperas untuk menghasilkan santan dengan proses yang singkat dengan tujuan agar minyak kelapa murni tidak berbau tengik. Minyak kelapa murni (virgin coconut oil) yang kandungan asam lemak jenuhnya tinggi menyebabkan proses oksidasi tidak mudah terjadi sehingga tidak mudah tengik. Namun jika kualitas minyak kelapa murni (virgin coconut oil) rendah, proses bau menjadi tengik akan berjalan lebih awal. ${ }^{3}$
Dari minyak kepala murni (virgin coconut oil) dengan penambahan sere dan daun dewa, didapat minyak gosok sebanyak 200 $\mathrm{ml}$ dan setelah diuji organoleptis sediaannya minyak gosok ini tidak menunjukan perubahan yang signifikan dari bentuk, bau dan warna, sehingga minyak gosok mampu bertahan selama tiga minggu dan bisa digunakan untuk kerik masuk angin.

\section{Hasil sediaan pertama jadi}

Warna : bening

Bau : kelapa dan sere

Bentuk: lengket dan licin

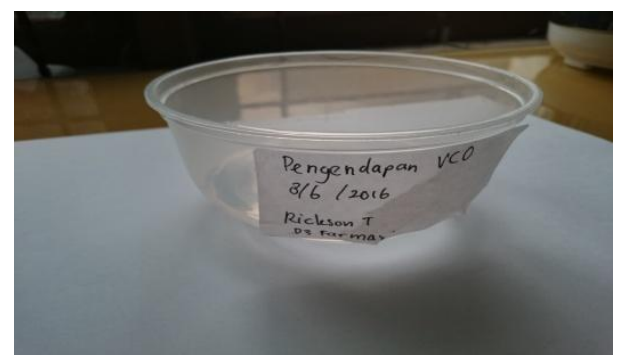

Gambar 1. Sediaan Minyak Gosok Awal

\section{Hasil sediaan setelah tiga minggu}

$\begin{array}{ll}\text { Warna } & \text { : bening } \\ \text { Bau } & \text { : kelapa dan sere } \\ \text { Bentuk } & \text { : lengket dan licin }\end{array}$




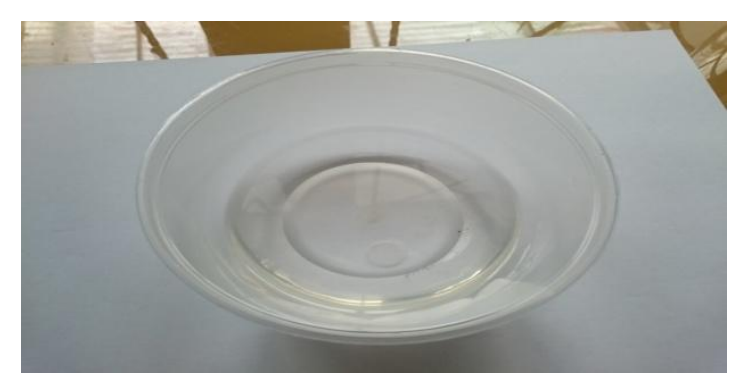

Gambar 2. Sediaan Minyak Gosok Setelah Tiga Minggu.

Dari hasil pengamatan daun dewa dapat menghasilkan sediaan setelah tiga minggu minyak gosok yang berwarna bening menunjukan sediaan minyak gosok dan dapat digunakan sebagai minyak dari minyak kelapa murni (virgin kerik maupun dioleskan pada kulit. coconut oil) dengan campuran sere dan daun dewa tidak ada perubahan dari warna, rasa, sedangkan bau sere mengalami penurunan sedikit.

\section{SIMPULAN}

Minyak gosok dapat digunakan untuk penyembuhan gelaja masuk angin, gigitan serangga, pengusir nyamuk dan bengkak di kulit sehingga tidak perlu menggunakan obat untuk penyembuhannya.

Berdasarkan hasil pengamatan yang diperoleh dari

\section{DAFTAR PUSTAKA}

wawancara Desa Bungursari Kabupaten Purwakarta sebagai sumber penelitiannya. Dapat disimpulkan bahwa pembuatan sediaan dengan metode pengendapan secara tradisional dengan bahan kelapa diperoleh minyak kelapa murni dengan campuran sere dan

1. Hidayat, R S. Kitab Tumbuhan Obat. Jakarta: Niaga Swadaya; 2015.Hal 103, 354.

2. Nahumarury, T P. Pembuatan Minyak Gosok. 2015.

3. Subroto, M A. Pandanus Cocos Oil. Jakarta: Penebar Swadaya; 2015. Hal 17-24. 